\title{
TFRS 9'a Geçişin Türkiye'de Halka Açık Bankaların Finansal Durum Tablolarına Etkileri*
}

\author{
Serhan KARAARSLAN** \\ Ozan GÜLHAN***
}

\begin{abstract}
ÖZET
Uluslararası Muhasebe Standartları Kurulu, 2008 yılında yașanan global kriz sonrası çokça eleştiri alan "UMS 39 - Finansal Araçlar: Muhasebeleştirme ve Ölçme" ilgili standardını değiştirmiştir. Ülkemizde de geçerli olmak üzere yeni "TFRS 9 - Finansal Araçlar" standardının hükümleri 1 Ocak 2018 tarihi itibariyle uygulanmaya başlanmıştır. Doğaları gereği finansal durum tablolarında önemli ölçüde finansal araç bulunduran bankalar için bu değişiklik büyük önem arz etmektedir. Bu çalış̧mada standart değişikliğinin, Türkiye'de halka açı bankaların finansal durum tablolarındaki değiş̧imler ile Avrupa Birliği ve Türkiye'deki otoriteler tarafindan yapılan etki analizlerindeki beklentiler karşılaş̧tırlmış ve toplam karşılıklar, sermaye yeterliliği standart oranı ile çekirdek sermaye yeterliliği oranı beklentileri ile gerçekleşmeleri arasinda uyumsuzluklar gözlemlenmiştir. Ayrıca Türkiye'de yerel mevzuat sebebiyle genel karşıllklar için bankalarda ilk defa ertelenmiş vergi varlğğ ayrılmış ve bu uygulama özkaynaklarda pozitif etki yaratmıştır.
\end{abstract} TMS 39.

Anahtar Kelimeler: Türkiye Muhasebe / Finansal Raporlama Standartları, Finansal Araçlar, TFRS 9,

JEL Sinıflandırmasi: $M 40$, M41.

\section{The Effect of TFRS 9 Implementation on Statements of Financial Position of Listed} Banks in Turkey

\section{ABSTRACT}

International Accounting Standards Board, has changed "IAS 39 Financial Instruments: Recognition and Measurement" which has been criticized largely after 2008 global crisis. The provisions of the new "TFRS 9 Financial Instruments" standard has been effective starting from January 1st, 2018 also for Turkey. This change has a vital importance for the banks which are holding vast amount of financial instruments in their portfolios due to their nature of business. In this study, the changes in the financial statements of listed banks in Turkey is being compared with the results in the impact analyses made by authorities from European Union and Turkey and some inconsistency was observed between expectations and results of total provisions, total capital ratio and Common Equity Tier 1 ratio. Furthermore, due to local regulation deferred tax assets realized for general provisions in banks for the first time in Turkey and it caused a positive effect in equity.

Keywords: Turkish Accounting / Financial Reporting Standards, Financial Instruments, TFRS 9, TMS 39. Jel Classification: M40, M41.

\footnotetext{
${ }^{*}$ Bu makale yüksek lisans tezinden üretilmiştir.

Makale Gönderim Tarihi: 09.08.2019, Makale Kabul Tarihi: 24.09.2019, Makale Türü: Araştırma Makalesi

** Bilim uzmanı, TEB Kosova, serhankaraarslan@gmail.com, Orcid ID: 0000-0002-5020-6918.

*** Dr., TEB Kosova, ozangulhan79@hotmail.com, Araştırma, ORCID ID: 0000-0002-1506-3982.
} 


\section{GİRIŞ}

Gelişen piyasalar ile hızlanan, kolaylaşan ve çoğalan sermaye hareketlerinin de etkisiyle finansal araçların muhasebeleştirilmesi ve ölçümü için muhasebe prensiplerinin ortaya koyulması zorunluluğu doğmuştur. Bu nedenle finansal araçlar ile ilgili standartlardan Uluslararası Muhasebe Standardı (UMS) 39 Finansal Araçlar: Muhasebeleştirme ve Ölçme 1998 yılında yayımlanmıştır. UMS 39 standardı, 2008 küresel krizi sonrasında, kredi zararlarının muhasebeleştirilmesini geciktirdiği ve karmaşık bir kurallar bütünü olduğu gibi eleştirilere maruz kalmıştır. Uluslararası Muhasebe Standartları Kurulu, bu eleştirilere yanıt vermek amacıyla üç aşamalı bir proje olan "Uluslararası Finansal Raporlama Standardı (UFRS) 9 - Finansal Araçlar" düzenlemesini hayata geçirmiştir. Bu proje 24 Temmuz 2014 tarihinde sonuçlandırılmış ve 1 Ocak 2018 tarihinden itibaren uygulamaya alınması kararlaştırılmıştır. Türkiye'de de muhasebe standartlarını yayımlamakla görevli otorite olan Kamu Gözetimi, Muhasebe ve Denetim Standartları Kurumu (KGK), "Türkiye Finansal Raporlama Standardı (TFRS) 9 - Finansal Araçlar" standardını yayımlamış ve yine 1 Ocak 2018 tarihi itibariyle zorunlu uygulamanın başlayacağını düzenlemiştir.

Uygulamanın etkilerinin önceden tespit edilmesi amacıyla uluslararası alanda Avrupa Bankacılık Otoritesi (EBA), Türkiye'de ise Bankacılık Denetleme ve Düzenleme Kurumu (BDDK) tarafindan etki analizleri yapılarak olası finansal etkiler konusunda finansal bilgi kullanıcılarının dikkati çekilmiştir. EBA ayrıca yeni standarda geçişin nicel ve nitel etkilerini içeren analiz raporları ile geçiş sonrası etkileri ortaya koymak için değerlendirme raporu yayımlamıştır.

UMS uygulamalarının ülkelerdeki muhasebeleştirme kalitesine olan etkileri çeşitli akademik çalışmalara konu olmuş ve olmaktadır. Bu çerçevede yapılan ülke analizlerinde bu uygulamaların yatırımcıların sahip olduğu bilgilerin arttırılması ve karşılaştırılabilir hale gelmesi nedeniyle olumlu etkileri olduğu sonuçlarına ulaşılmıştır.

Her ne kadar TFRS 9'un uygulamaya alınması üzerinden çok uzun zaman geçmese de ilk finansal tablolarda çeşitli etkiler görülmeye başlamıştır. Bu çalışmada, Türkiye'de halka açık bankaların geçiş sonrası finansal durum tablolarındaki değişimler ile beklentiler karşılaştırılmış ve EBA'nın öngörülerine uygun ve BDDK öngörülerinin tersine toplam karşılık tutarında artış gözlemlenmiştir. Bunun yanında Çekirdek Sermaye Yeterliliği Oranı'nda (ÇSYO) artış, ertelenmiş vergi varlığı tutarında artış Sermaye Yeterliliği Standart Oranı'nda (SYSO) azalış ortaya çıkmıştır. Çalışmada kullanılan tutarlar aksi belirtilmedikçe bin Türk Lirası veya bin ABD Doları cinsinden ifade edilmektedir.

\section{TFRS 9 İLE BANKALARI İLGILENDİREN KURAL DEĞİŞIKLIKLERİ VE YAPILAN ETKİ ANALIZZLERI}

Teknolojinin gelişmesi ve ülkelerin korumacı ekonomi politikalarından uzaklaşması sebebiyle, sermayenin ülkeler arası dolaşımı hem kolaylaşmış hem de hızlanmıştır. Bu durum piyasaların gelişmesini sağlamış olsa da, piyasalar ve piyasalarda kullanılan araçlar ile ilgili düzenlemeler oluşturulması ihtiyacını doğurmuştur. $\mathrm{Bu}$ nedenlerle finansal araçların muhasebeleştirilmesi ve ölçümü için muhasebe prensipleri oluşturulmuştur. Finansal araç, Türkiye Muhasebe Standardı (TMS) 32'de "Bir işletmenin finansal varliğ ile diğer bir 
işletmenin finansal borcunda ya da özkaynağa dayalı finansal aracinda artışa neden olan herhangi bir sözleşmedir" ş̧eklinde tanımlanmaktadır.

Finansal araçlara ilişkin uygulamaların standartlaştırılması adına, Uluslararası Muhasebe Standartları Komitesi (Nisan 2001'den sonra yeniden yapılandırma amaciyla Uluslararası Muhasebe Standartları Kurulu (UMSK) adını almıştır) ve Kanadalı Muhasebeciler Enstitüsü 1989 yılında finansal araçlar standardı için bir proje başlatmışlardır. Başlangıçta ölçme, sinıflandırma, finansal tablolarda sunum ve yapılması gereken açıklamaları da içeren tek bir standart oluşturulması amaçlansa da gelen eleştiriler sebebiyle standardın ikiye ayrılmasına karar verilmiştir. Sonuç olarak UMS 32 Finansal Araçlar: Sunum ve Açıklamalar standardı Haziran 1995, UMS 39 Finansal Araçlar: Muhasebeleştirme ve Ölçme standardı Aralık 1998'te yayımlanmıştır (Demir, 2015: 2, 51-52).

Finansal araçlar standardına ilişkin, yayımını takip eden süreçte denetçiler ve analistler tarafindan oldukça fazla görüş, fikir, yorum ve eleştiri alınmıştır. Buna bağlı olarak UMSK eleştiri alan birçok kuralı gözden geçirmiş, bunun sonucunda standartta bazı değişiklikler ve düzeltmelere gitmiştir. Bu değişikliklere neden olan faktörlerden bazıları;

- Son yıllarda finansal piyasalarda yaşanan büyüme,

- Ekonominin temel göstergelerindeki dalgalanmalar,

- Yeni finansal araçların açıklanması olarak gösterilebilir.

UMS 39 standardının uygulaması ile ilgili en önemli UMSK kararının ise 2008 yılında açıklanan 1004 numaralı karar olduğu söylenebilir. Bu karara göre tamamıyla yeni bir muhasebe prensipleri seti uygulamaya koyularak UMS 39'un uygulamasina son verilmiştir. $\mathrm{Bu}$ muhasebe prensipleri UFRS 9 - Finansal Araçlar standardında toplanmıştır (Bottaro, 2017:6).

Finansal araçların sınıflandırma, muhasebeleştirme ve ölçüm kuralları için yeni standardın diğer işletmeler gibi banka finansal tablolarına da etkisi olacaktır. Ancak bankalar özelinde bazı değişikliklerin, finansal tablolar üzerinde daha fazla etki göstermesi muhtemeldir.

TFRS 9, 1 Ocak 2018'den sonra başlayan dönemlerde uygulanacak olmakla birlikte ölçüm metodolojisindeki değiş̧ime bağlı oluşacak ölçüm farkları, geçmiş yıllar kar veya zararları ile ilişkilendirilmektedir (KGK, 2019: Paragraf 7.2.15). Ayrıca kapsam dahilindeki bankalar geçmiş dönem finansal tablolarını ilgili geçiş hükümleri uyarınca yeniden düzenlememiştir. Sınıflandırma ile ilgili değiş̧ikliklerde cari dönem finansal tablolarında yer almaktadir.

Bunlardan en fazla etki göstermesi bekleneni ise gerçekleşmiş kredi zararları modelinden beklenen kredi zararları modeline geçilmesidir. TMS 39'a göre kredi zararlarının muhasebeleştirilmesi yalnızca objektif bir kanıtın varlığı durumunda söz konusu olabilmekte iken, TFRS 9 ile bu yükümlülük kaldırılmaktadır. Bu durumda, standart değişikliği öncesinde kredi zararlarını önceden belirlenmiş yüksek oranlara göre ayırmayan bankaların toplam kredi zararlarının artması beklenmektedir. Zira TFRS 9'a göre henüz değer düşüklügüne uğramamış krediler için dahi zarar karşllığı ayrılmaktadır, kredi kalitesine göre finansal alacaklar için, ömür boyu (ikinci ve üçüncü aşama) veya 12 aylık beklenen kredi zararları 
üzerinden karşılık ayrılmaktadır. Artan karşı1ık tutarına paralel olarak geçmiş yı1lar kar veya zararları ile dönem net karı veya zararı tutarlarında da değişim gözlemlenebilecektir.

Yeni standardın getirmiş olduğu bir başka değişiklik ise yeni sınıflandırma metodolojisi olup, TFRS 9 uyarınca finansal varlıklar, ölçümleme çeşitlerine göre sınıflandırılmaktadır. Bu metodoloji finansal varlıklar ve yükümlülükler için iki temel gruba odaklanmaktadır. Bunlar (Bottaro, 2017: 78-79);

- Borçlanma araçlarının sınıflandırılma ve ölçüm süreci, bankaların seçmiş olduğu iş modeline veya sadece anapara ve faiz ödemelerinden oluşma (SAFÖ) testi sonuçlarına göre yapılmaktadır,

- Ö̈zkaynağa dayalı araçların sınıflandırılma ve ölçümü kar veya zarara yansıtılarak yapılmaktadır, ancak bankaların veya finansal kuruluşların alım satım amaçlı ellerinde bulundurdukları finansal araçları, gerçeğe uygun değer farkı diğer kapsamlı gelire yansıtılarak ölçmeyi seçmesi durumu ise istisnai olarak ortaya çıkmaktadır.

Finansal varlıkların sınıflandırılması hususunda bir başka önemli konu ise SAFÖ testleridir. Sözleşmeye bağlı nakit akışlarının karakteristik özelliklerinin, bankaların seçmiş olduğu iş modeline uyumunun teyit edilmesi bu test sayesinde yapilabilmekte olup, finansal varlığın hangi grupta sınıflandırılabileceğine karar verilmektedir. Bu sınıflandırma kararında bankaların iş modeli de göz önünde bulundurulmaktadır. Bankaların bu ölçüm gerekliliklerin yerine getirecek sistemleri kurmaları önem arz etmektedir.

Finansal riskten korunma muhasebesi açısından ise standardın daha anlaşılır ve yalın olduğu görülmektedir. Eski standardın katı kural bazlı etkinlik testi uygulamasına devam edilmemekte ve bankalara belirli şartların oluşması durumunda finansal riskten korunma hükümlerinin uygulama hakkı verilmektedir.

Yukarıda aktarılan standart değişikliklerinin, bankaların finansal durum tabloları ve hisse fiyatları üzerinde de etkileri olması beklenmektedir. Finansal durum tablosu üzerindeki etkilerin düzenleyici kurumların karşılık uygulamasına ve bankacılıkla ilgili yasal düzenlemelere göre farklılık gösterebilecektir. TFRS 9'a geçiş öncesi Türk bankacılık sisteminde bankalar, genel karşılıkları için ertelenmiş vergi varlığı ayırmamakta iken standarda geçiş ile birlikte ayırabilecektir.

Nispeti değişmekle birlikte Türkiye'de faaliyette bulunan ve TFRS 9'u uygulayan bankaların finansal tablolarında beklenen bazı değişiklikler aşağıdaki gibi sıralanabilir;

- Toplam karşılık tutarında artış,

- $\quad$ Ertelenmiş vergi varlığ 1 tutarında artış,

- $\quad$ Geçmiş yıllar kar veya zararı ile dönem karı veya zararında artış,

sinıflandırılmasi.

Finansal varlıkların yeni sınıflandırma kurallarına göre yeniden

Toplam karşılık tutarındaki artış ile birlikte, maruz kalınan risklerin birinci aşamadan ikinci aşamaya transferi sırasında, ölçüm metodolojisinde kullanılan zaman aralı̆̆ 1 da 12 aydan finansal varlığın ömrü boyunca olacak şekilde uzamaktadır. Bu durum kredi zararları karşılıkları tutarında "tepe etkisi" ne yol açabilecektir, yani ekonomik gerileme dönemlerinin 
başlangıcında karşıllık tutarında keskin bir artış gözlemlenebilecektir (Cohen ve Edwards, 2017:49).

İleriye dönük bilginin kullanılmasını önleyen engeller ve kredi riskinde önemli derecede artsşı tespiti için gerekli sistemin etkin bir şekilde uygulanamaması, tepe etkisinin ve dönemsellik riskinin artmasına neden olabilmektedir. Bunlardan başka tepe etkisine tesir eden başka faktörler de bulunmaktadır.

Örneğin maruz kalınan risklerin vadelerinin, 12 aylık beklenen kredi zararları ölçüm metodolojisinden ömür boyu beklenen kredi zararlarına geçiş sonucu hesaplanan zarar tutarı ile pozitif bir ilişkisi olduğu söylenebilir. Bütün şartların aynı kaldığı durumlarda bile daha uzun vadeli risklerin daha fazla tepe etkisi yaratması beklenmektedir. Bu bağlamda vadesine bir yıl veya daha az kalmış risklerin tepe etkisi yaratması beklenmemektedir. Bir diğer faktör olarak ise dönemselliğe hassas olan borçlulara maruz kalma derecesi gösterilebilir. Borçlularının önemli bir kısmı dönemsellikten fazlaca etkilenen bankalarda tepe etkisi ve aslında ekonomik kayıpların da daha fazla olması beklenmektedir. Son olarak karlılığı dizginleyici yönetim teşvikleri de tepe etkisinin azaltılmasında rol oynayabilecektir. Teorik olarak karlılıktaki oynaklığın azaltılmasına yönelik olarak yönetime verilen teşvikler (prim, bonus v.b.) alacakların birinci aşamadan ikinci aşamaya geçişinin ertelenmesine neden olabilecektir. (ESRB, 2019: 3-31)

UFRS'lerde yapılan değişikliklerin genel olarak ihtiyaca uygun ve güvenilir bilginin üretilmesi sonucunu doğurması beklenmektedir. Bu nedenle standart geliştirmelerinin doğru bilginin oluşturulması ve bilgi kullanıcılarına ulaştırılması konusunda önemli olduğu düşünülmektedir.

TFRS 9 sürecinin Türk bankacılık sektörüne etkilerinin ölçülmesi adına BDDK tarafından Eylül 2016 ve Haziran 2017 aylarında anket çalışmaları yapılmıştır. Bu çalışmaların sonuçları EBA'nın raporları kadar detaylı bir şekilde ortaya konulmasa da, BDDK tarafından 29 Aralık 2017 tarihinde yapılan "Karşıılı Yönetmeliği Hakkında Basın Açıklaması"nda kendine yer bulmuştur. Söz konusu açıklamada BDDK'nın TFRS 9 standardına geçiş süresince mevzuat çalışmalarına değinilmekte ve uluslararası iyi uygulamaların takip edildiği belirtilmektedir. Çalışmanın ana amacı ise; "TFRS 9 kapsamında karşıllk ayrllmasina ilişkin bankacıllk sektörünün hazırllk durumunu ve TFRS 9'un özellikle karşıllk seviyeleri ile sermaye yeterliliği üzerine etkilerini değerlendirmek" olarak ifade edilmektedir (BDDK, 2017:1-2).

BDDK'nın çalışmalarına 49 banka katılmıştır ve bunlardan 36'sı, geçiş tarihi itibarıyla, beklenen kredi zararı karşıllı̆ı hesaplayabilecek durumdadır. Bankaların TFRS 9'u uygulama durumları da farklılık göstermekte olup, alınan yanıtlara göre 6 bankanın geç uygulama yapacağı ve 9 bankanın ise TFRS 9'u hiç uygulamayacağı belirtilmektedir.

İkinci analiz çalışmasında kredi portföyünün $\% 78,1$ 'ine sahip 20 bankanın verileri kullanılmıştır. Bu analize göre;

- $\quad$ Toplam karşıll1k miktarı \%4,1 (2.565.000 TL) azalış,

- $\quad$ ÇSYO'da 33 baz puan ve

- $\quad$ SYSO'da 21 baz puan artış meydana geleceği beklenmektedir. 
EBA ise, TFRS 9 öncesi etki analizi yapmak amacıyla 2016 ve 2017 yıllarında iki analiz raporu yayımlamıştır. Bu raporlara, 2018 Aralık ayında yayımladığı ve geçiş sürecinin ilk etkilerini değerlendirdiği raporu ile devam etmiştir. Ancak bu çalışmada 2016 ve 2017 yılı çalışmalarının nitel sonuçları arasında yer alan ÇSYO, SYSO ve toplam karşılık tutarı analiz edilmiştir. Her iki analiz raporunun örnekleminin yüzde doksanından fazlası, "Global Sistemik Önemli Banka veya Diğer Sistemik Önemli Banka” kategorisinde yer almaktadır.

"Global Sistemik Önemli Banka" listesi, global sistemik indikatörler açıklamalarına dair EBA rehberlerini uygulayan ve yıl sonları itibariyle 200.000.000 USD üstünde riske maruz bulunan bankalardan oluşmaktadır. Bu şekilde Avrupa Birliği bankalarının sistemik riskliliği daha yakından değerlendirilebilmektedir. Diğer Sistemik Önemli Bankalar listesi ise sistemik önemlilikleri sebebiyle finansal istikrar adına risk taşıyan diğer bankalardan oluşmaktadır. Analiz raporlarında bu bankaların kullanılmış olması sektör genelindeki etkinin daha gerçeğe yakın tahmin edilebilmesi sonucunu doğurmuştur.

Bahsi geçen EBA çalışmalarında nicel sonuçlar detaylı bir şekilde analiz edilmekle birlikte nitel sonuçlara da yer verilmiştir. Nicel sonuçlar açısından, birinci etki analizi çalışmasında toplam karşılıklarda \%18 artış, ÇSYO'da 59 baz puan azalış ve SYSO'da 45 baz puan azalış beklentisi ortaya çıkmakta iken bu oranlar ikinci etki analizi çalışmasında sırasıyla \%13 artış, 45 baz puan azalış ve 35 baz puan azalış kayıt edilmiştir. Nitel sonuçlarda ise bankaların geçişe hazırlık süreci ile ilgili çeşitli noktalara değinilmektedir. Bunlar (EBA, 2016:5-6, EBA, 2017: 5-6);

- Birçok banka test veya sistemlerin inşa edilmesi aşamasındadır. Kısıtlı kaynaklar sebebiyle küçük ölçekli bankalar geçiş sürecinde geride kalmıştır.

- Temel paydaşların sürece müdahilliği açısından sağlam bir yönetim sürecine ihtiyaç olduğu ortaya koyulmaktadır.

- $\quad$ Birçok anket katılımcısı banka, TFRS 9 uyum sürecini paralel geçiş yöntemi ile test etmeyi planlamaktadır.

- Bankalar genel olarak ellerinde hali hazırda bulunan tanımlamalar, süreçler, sistemler, modeller ve veriyi kullanarak TFRS 9 geçişini yapmayı hedeflemektedirler.

- Veri kalitesi, tarihi verilerin kullanılabilirliği ve kredi riskindeki önemli artışın değerlendirilmesi konuları bankaların en çok zorluk yaşayabileceği noktalar olarak görülmektedir.

- $\quad$ Sınıflandırma ve ölçüm değişikliklerinin bankaların genelinde önemli etki yaratmayacağı görüşü hakimdir.

- $\quad$ TFRS 9'un değer düşüklüğü ile ilgili (kredi riskinde önemli derecede artış gibi) bazı temel hükümlerinin yorumu ve uygulaması oldukça zorlayıcı görülmektedir.

- $\quad$ Birçok bankanın, ana ölçü olmasa da kredi riskinde önemli artış ölçüsü olarak, vade tarihini 30 gün geçme kriterini kullanacağı anlaşılmaktadır.

- $\quad$ Anket çalışmasına katılan bankaların \%75'i kar veya zarardaki oynaklığın artacağı görüşündedir. Birçok katılımcı bu oynaklığın, birinci aşamadan ikinci aşamaya geçerken (12 aylık beklenen kredi zararları ) maruz kalınan "tepe etkisi” nedeniyle olacağını belirtmektedir.

- $\quad$ EBA, daha sık1 modellerin, eğer doğru adapte olabilirse TFRS 9 içinde uygun olacağ1 görüşündedir. 
- $\quad$ Anket sorularına alınan yanitlara göre, TFRS 9'un bankaların kredi verme uygulamalarında değişikliğe yol açacaktır. Ancak bu etkinin büyüklüğü ile ilgili bankaların detaylı bir tahmini bulunmamaktadır.

Her iki çalışmada yer alan tahminler farklı olası sonuçlara işaret etmektedir. Şekil 1'de karşılıklar yönünden yeni uygulamanın gerçekleşen değerlerine yer verilmektedir. Söz konusu etki değerlendirildiğinde; Aralık 2017 ile Ocak 2018 toplam karşılık tutarları karşılaştırıldığında bu tutarın 109.583.350.000 TL'den 111.293.490.000 TL'ye çıkarak $\% 1,56$ 'lık bir artış yarattığ görülmektedir. Literatürde yerini bulan tepe etkisinin, Türk bankacıllk sektörü için Avrupa birliği beklentilerine göre daha düşük düzeyde gerçekleştiği izlenmiştir. Bu duruma, uygulama öncesinde Türk bankacilık sektörünün ayırmakta olduğu asgari sabit oranlı karşılık sisteminin etki ettiği değerlendirilmektedir.

Şekil 1. TFRS 9'un Türk Bankacılık Sektörüne Gerçekleşmiş Beklenen Kredi Zararları Etkisi

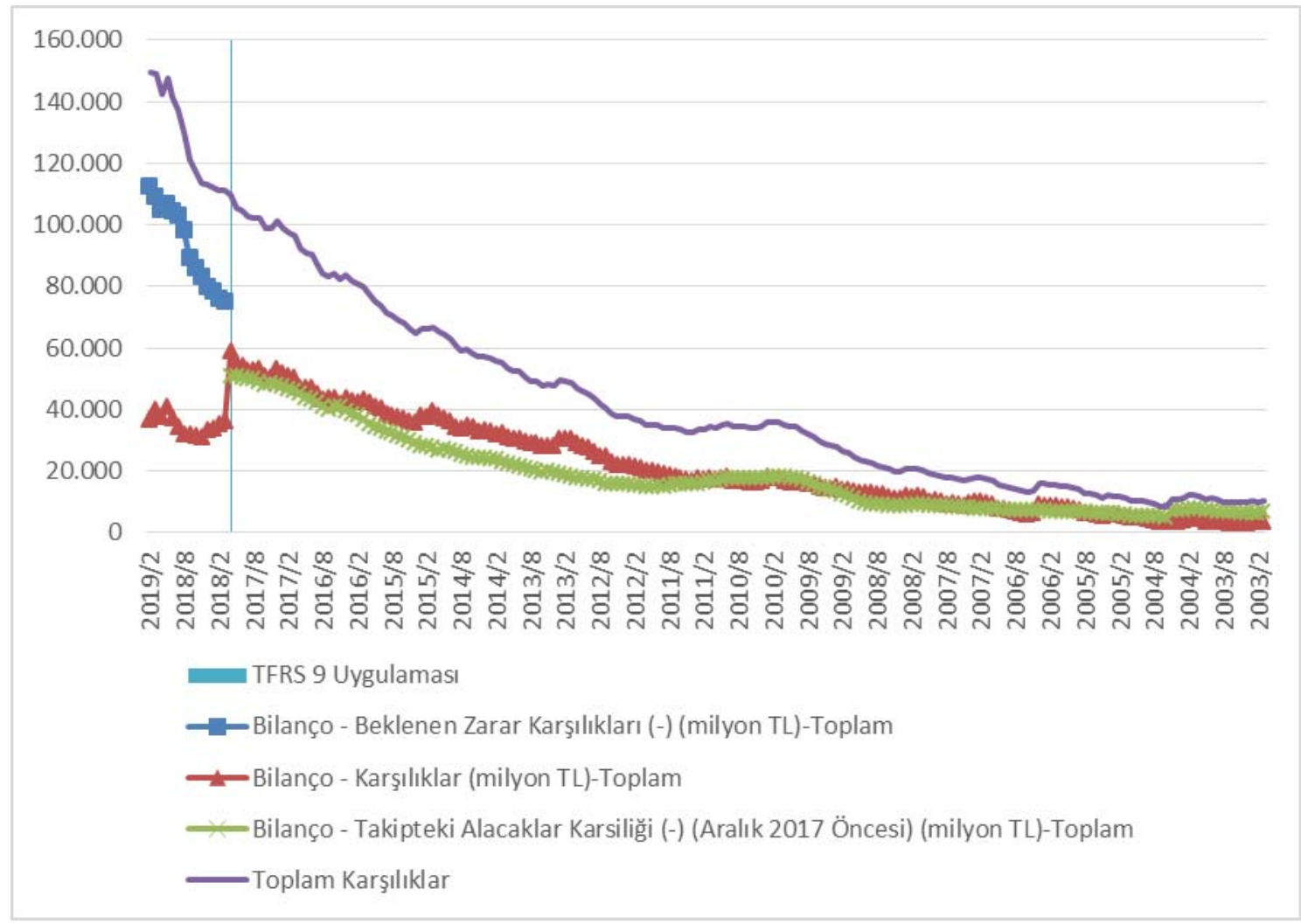

Kaynak: BDDK, Aylık Bankacılık Sektörü Verileri.

Toplam karşılıklardaki bu artışta, uygulamanın yanı sıra ekonomiye ilişkin olumsuz öngörülerinde rol oynadığı değerlendirilmektedir. Nitekim sektörün toplam takipteki alacaklar kaleminde, BDDK'nın yayımladığı Türk bankacılık sektörü verilerine göre tahminlerin yapıldığı Eylül 2016 ve Haziran 2017 dönemlerine göre önemli artış görülmektedir. Bu dönemler, Şubat 2019 tarihindeki toplam takipteki alacaklar ile karşılaştırıldığında sırasıyla $\% 88,07$ ve \%69,38 artış olduğu görülmektedir. Aynı dönemler USD bazında karşılaştırıldığında ise sırasıyla $\% 6,27$ ve \%12,07 artış bulunmaktadır ve ikinci anket ölçümü 
sırasında 17.496 Milyar USD olan takipteki alacaklar toplamı 2019 Şubat ayı itibarıyla 19.608.000.000 USD olarak gerçekleşmiştir.

Şekil 2. Türk Bankacılık Sektörünün Takipteki Alacaklar Kaleminin Değişimi

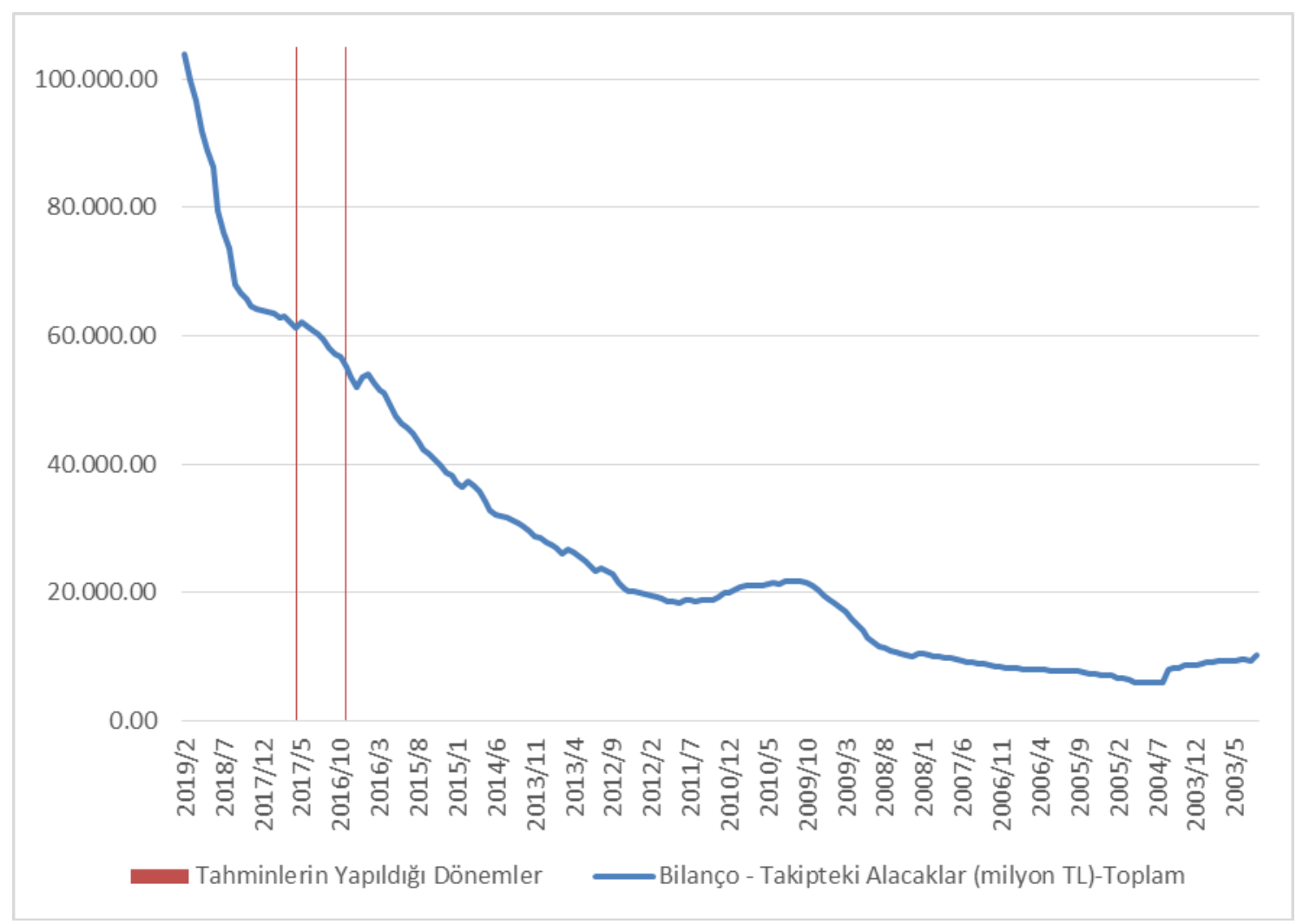

Kaynak: BDDK, Aylık Bankacılık Sektörü Verileri.

\section{UYGULAMA}

Bu çalışmanın amacı, TFRS 9'a geçişin Türkiye'de faaliyette bulunan tüm halka açık bankaların finansal durum tablolarına etkisinin araştırılmasıdır. $\mathrm{Bu}$ amaç için, EBA ve BDDK'nın geçmiş dönemlerde geçiş sürecine yönelik yaptığı etki analizi çalışmalarında öne çıkardığı finansal durum tablosu kalemleri ile sermaye yeterliliği oranları beklentileri, bu bankaların bağımsız denetim raporlarından, banka internet sitelerinden, BDDK ve Türkiye Bankalar Birliği'nin interaktif veri sisteminden edinilen bilgiler ile karşılaştırılmıştır. Bir önceki bölümde değinilen BDDK ve EBA etki analizlerinde TFRS 9 uygulamasının genel olarak Türkiye ve Avrupa Birliği Bankacılık Sistemlerinde yarattığı olası etkiler incelenmekte iken, bu çalışmanın uygulama kısmı Borsa İstanbul'da halka açık 10 bankanın finansal tablolarında yeni uygulamanın gerçekleşmiş etkilerini incelemektedir.

Geçiş etkilerinin analizi sırasında finansal durum tablolarındaki etkiler, kapsam dahilindeki bankaların bağımsız denetim raporlarında yer alan 1 Ocak 2018 açılış finansal durum tablolarındaki değişimlerin verildiği finansal tablolardan alınmıştır. ÇYSO ve SYSO ise eldeki verileri ile bu oranların geriye dönük hesaplanması mümkün olmadığından Aralık 
2017 ve Ocak 2018 oranları ise BDDK ve Türkiye Bankalar Birliği internet sitelerinden elde edilen veriler ile karşılaştırılmıştır.

TFRS 9'a geçiş ile birlikte, kapsamdaki bankaların 1 Ocak 2018 açılış finansal durum tablolarındaki beklenen kredi zararlarında $2.166 .640 \mathrm{TL}$ ve \%4,04 artış gözlemlenmiştir. Beklenen kredi zararlarındaki artışın dağılımı;

- $\quad$ Kredilerden beklenen zarar karşlıklarının yeniden ölçülmesinden 1.305.528 TL brüt zarar,

- Finansal varlıklardan beklenen zarar karşılıklarının yeniden ölçülmesinden 169.439 TL brüt kar,

- Gayrinakdi kredilerden beklenen zarar karşllıklarının yeniden ölçülmesinden 1.210.538 TL brüt zarar ve

- Diğer aktiflerden beklenen zarar karş1lıklarının yeniden ölçülmesinden 179.987 TL brüt kar şeklinde oluşmuş̧ur.

BDDK'nın yaptığı etki analizi çalışmasının tam tersi yönde bir etki gerçekleşmiştir. BDDK anket sonuçlarına göre sektörün karşıllk toplamında $\% 4,1$ azalış beklenmekte iken bu oran \%4,04 artış olarak gerçekleşmiştir. Buna karşın bu artış, EBA'nın birinci anket çalışmasındaki \%18 lik artış beklentisi ile ikinci anket çalışmasındaki \%13 lük artış beklentisinin de altında kalmaktadır. Bu duruma, 2018 yılı sonlarına doğru, Türkiye'nin ekonomik konjonktüründeki olumsuz gelişmelerin sebep olduğu düşünülebilir. Nitekim yılbaşına göre Aralık 2018'de işsizlik oranı yüzde 2,6, TÜFE yüzde 8,38, USD/TL kuru yüzde 40 ve TCMB gecelik borç verme faizi yüzde 16,25 artarken, sanayi üretim endeksi 13 puan azalmıştır.

Değişikliğin ertelenmiş vergi etkisi boyutuna bakıldığında ise daha büyük bir fark ortaya çıkmaktadır. BDDK tarafından 20 Eylül 2017 tarihinde yayımlanan "Tekdüzen Hesap Planı ve İzahnamesi Hakkında Tebliğ"e göre genel karşıllklar (birinci ve ikinci aşamadaki krediler için ayrılan TFRS 9 beklenen zarar karşılıkları) için 1 Ocak 2018 tarihinden itibaren ertelenmiş vergi varlı̆̆ hesaplanabilmektedir. Bundan önce BDDK'nın 18 sayılı tebliğine ilişkin 8 Aralık 2004 tarihli ve BDDK.DZM.2/13/1-a-3 sayllı genelgesi uyarınca, genel karşılıklar ve serbest karşıllklar için ertelenmiş vergi aktifi kaydı yapılamamakta idi. Serbest karşılıklar için halen ertelenmiş vergi hesaplaması halen yapılamamaktadır. Bu nedenler ile daha önce ayrılan genel ve özel karşılıklar iptal edilerek, birinci ve ikinci aşamadaki krediler için ilk defa ertelenmiş vergi hesaplanmış ve bu tutar açılış finansal durum tablolarına yansitılmışır.

Kapsamdaki bankaların açılış finansal tablolarında yapılan düzeltmeler incelendiğinde toplam 4.766.256 TL net ertelenmiş vergi varlığı oluşmaktadır. Bu fark özkaynağı arttırıcı bir etki yaratmaktadır. Birinci ve ikinci aşamadaki finansal varlıklar için beklenen zararların hesaplamasından oluşan farka dair ilk defa hesaplanan ertelenmiş vergi varlığı tutarı 5.215.838 TL iken, genel ve özel karşılıkların iptal edilerek üçüncü aşamada sınıflandırılan finansal varlıklar için hesaplanan ertelenmiş vergi yükümlülüğü 449.582 TL'dir.

TFRS 9' a geçiş ile birlikte bankaların finansal bilgilerini raporlama biçemlerinde değişiklikler olmuş̧ur. Buna bağlı olarak önceden genel karşılıklar ve takipteki alacaklar 
karşılığında izlenen tutarlar, yeniden hesaplama ve sınıflandırma etkileriyle birlikte beklenen kredi zararları karşılığı hesabında takip edilmeye başlanmıştır.

EBA ve BDDK'nın uygulama öncesi yaptıkları etki analizi çalışmalarında yer verilen diğer iki önemli oran, ÇSYO ve SYSO oranıdır. EBA bu oranların sırasıyla 59 baz puan ve 45 baz puan düşüş göstereceğini öngörmüştür. Bunun tersi şekilde BDDK ise sirasiyla 33 baz puan ve 21 puan artış öngörmüştür. Geçiş sonrası Aralık 2017 ve Ocak 2018 sektör verileri karşılaştırıldığında, ÇSYO 17 baz puan artarken, SYSO 4 baz puan azalmıştır. Yapılan analiz 2018 Ocak ayı içerisinde gerçekleşmiş olayların etkisini içermediğinden, konuya ilişkin net bir değerlendirme yapılmasının uygun olmayacağı düşünülmektedir. Aşağıdaki tabloda EBA ve BDDK etki analizleri ile gerçekleşmelerin karşılaştırmasına yer verilmektedir.

Tablo 1. TFRS 9'a Geçişin Toplam Karşılıklar, ÇSYO ve SYSO Üzerine Gerçekleşmiş Etkilerinin EBA ve BDDK Beklentileri ile Karşılaştırılması

\begin{tabular}{|l|l|l|l|l|}
\hline İlgili Kalem & $\begin{array}{l}\text { EBA 1. Etki Analizi } \\
(\mathbf{1 0 . 1 1 . 2 0 1 6 )}\end{array}$ & $\begin{array}{l}\text { EBA 2. Etki Analizi } \\
\mathbf{( 1 3 . 0 7 . 2 0 1 7 )}\end{array}$ & $\begin{array}{l}\text { BDDK Etki Analizi } \\
\mathbf{( 2 9 . 1 2 . 2 0 1 7 )}\end{array}$ & $\begin{array}{l}\text { Gerçekleşen } \\
\text { (Ocak 2018) }\end{array}$ \\
\hline Toplam Karş1lıklar & \%18 Artış & \%13 Artış & \%4,1 Azalış & \%4,04 Artış \\
\hline ÇSYO & 59 baz puan Azalış & 45 baz puan Azalış & 33 baz puan Artış & 17 baz puan Artış \\
\hline SYSO & 45 baz puan Azalış & 35 baz puan Azalış & 21 baz puan Artş̧ & 4 baz puan Azalış \\
\hline
\end{tabular}

Kaynak: EBA, BDDK, Banka İnternet Siteleri.

Yukarıdaki tabloda kapsam dahilindeki bankalar üzerindeki toplam etkiye yer verilmekle birlikte ilerleyen kısımda bu bankaların üzerindeki etkiler detaylı şekilde incelenecektir. Bu inceleme kapsamında bankaların 31 Mart 2018 tarihli konsolide olmayan bağımsız denetim raporlarında açıkladıkları bilgilerden yararlanılacaktır. Ayrıca 2018' in birinci çeyreğinde, risk ağırlıklı varlıklarda gerçekleşmesi beklenen değişimlerin etkileri saklı kalmak kaydıyla, Türkiye Bankalar Birliği'nin interaktif veri sistemi ve bankaların internet siteleri kullanılarak uygulama öncesi ve sonrası ÇSYO ve SYSO değişimleri gözlemlenecektir.

Tablo 2. TFRS 9'un Borsa İstanbul'da Halka Açık Bankaların Değer Düşüklüğü Karşıllğı Tutarı, ÇSYO ve SYSO Üzerine Etkileri

\begin{tabular}{|c|c|c|c|c|c|}
\hline \multirow[b]{2}{*}{ Banka Adı } & \multirow[b]{2}{*}{$\begin{array}{l}\text { Toplam Değer Düşüklüğü } \\
\text { Karşılığındaki Değişim (\%) }\end{array}$} & \multicolumn{2}{|c|}{ SYSO } & \multicolumn{2}{|c|}{ ÇSYO } \\
\hline & & $\begin{array}{c}\text { Geçiş } \\
\text { Öncesi } \\
\text { (Aralık } \\
\text { 2017) }\end{array}$ & $\begin{array}{c}\text { Geçiş } \\
\text { Sonrası } \\
\text { (Ocak } \\
\text { 2018) } \\
\end{array}$ & $\begin{array}{c}\text { Geçiş } \\
\text { Öncesi } \\
\text { (Aralık } \\
\text { 2017) }\end{array}$ & $\begin{array}{c}\text { Geçiş } \\
\text { Sonrası } \\
\text { (Ocak } \\
\text { 2018) } \\
\end{array}$ \\
\hline Akbank T.A.Ş. & 0,06 Artış & 17,03 & 16,82 & 15,33 & 14,66 \\
\hline ICBC Turkey Bank A.Ş. & 16,59 Azalış & 14,41 & 15,3 & 13,16 & 14,71 \\
\hline Şekerbank Türk A.Ş. & 82,79 Artış & 13,11 & 15,4 & 12,83 & 12,21 \\
\hline Türkiye İş Bankası A.Ş. & 1,04 Artış & 16,66 & 16,51 & 14,03 & 13,78 \\
\hline Yap1 ve Kredi Bankası A.Ş. & 10,05 Artış & 14,49 & 14,02 & 10,91 & 10,82 \\
\hline Türkiye Vakıflar Bankası TAO & 2,90 Azalış & 14,16 & 15,37 & 11,47 & 12,22 \\
\hline Türkiye Halk Bankası A.Ş. & 6,85 Azalış & 14,18 & 12,01 & 12,56 & 13,37 \\
\hline Türkiye Garanti Bankası A.Ş. & 4,69 Artış & 18,68 & 18,03 & 16,47 & 15,82 \\
\hline Denizbank A.Ş. & 4,43 Artış & 19,50 & 19,02 & 13,67 & 13,35 \\
\hline QNB Finansbank A.Ş. & 12,77 Artış & 14,99 & 14,62 & 12,32 & 12,09 \\
\hline
\end{tabular}

Kaynak: Türkiye Bankalar Birliği, BDDK, Banka İnternet Siteleri. 
Yukarıdaki tabloda bankaların toplam değer düşüklüğü kalemindeki ve SYSO ile ÇSYO’daki değişiklikler gösterilmektedir.

Kapsam dahilindeki tüm bankalar, 31 Mart 2018 tarihli konsolide olmayan finansal tabloları ve dipnotlarında yer alan açıklamalarda, TFRS 9'a geçiş ile birlikte geçmiş dönem finansal tablolarını yeniden düzenlemeyi seçmediği belirtilmektedir. Dolayısı ile geçişin etkileri yalnızca açılış finansal tabloları ve devam eden dönemlerde oluşturulacak finansal tablolar üzerinde olacaktır.

Akbank T.A.Ş., TFRS 9 Finansal Araçlar Standardına İlişkin Açıklamalar başlıklı dipnotunda, 31.12.2017 tarihli TFRS 9 öncesi finansal tablolar ile 01.01.2018 tarihli TFRS 9 sonrası finansal tablolar arasında bazı mutabakat tablolarına yer vermektedir. Bunlardan değer düşüklüğü karşılıklarının TFRS 9'a geçişte açılış bakiyesinin mutabakatı başlıklı bölümde ise toplam değer düşüklüğü karşılıklarında gerçekleşen etki gösterilmektedir. Buna göre; 7.101.857 TL olan toplam değer düşüklüğü karşılı̆̆g, 4.458 TL artarak, 7.106.315 TL'ye yükselmektedir. $\mathrm{Bu}$ artış yüzdesel olarak, \%0,06 şeklinde ifade edilebilmektedir. Akbank T.A.Ş.'nin uygulama öncesi 17,03 olan SYSO, uygulama sonrasında 16,82'ye düşmektedir. ÇSYO ise 15,33'ten 14,66'ya düşmektedir.

ICBC Turkey Bank Anonim Şirketi, XXVII. Sınıflandırmalar dipnotunda, 31.12.2017 tarihli TFRS 9 öncesi finansal tablolar ile 01.01.2018 tarihli TFRS 9 sonrasi finansal tablolar arasında mutabakat tablosuna yer vermektedir. Bu tabloda değer düşüklüğü karşılıkları da dahil olmak üzere yeniden sınıflandırma ve yeniden ölçüm farkları yer almaktadır. Buna göre; 172.043 TL olan toplam değer düşüklüğü karş1lığı, 28.543 TL azalarak, 143.500 TL'ye düşmektedir. $\mathrm{Bu}$ azalış yüzdesel olarak, \%16,59 şeklinde ifade edilebilmektedir. ICBC Turkey Bank Anonim Şirketi'nin uygulama öncesi 14,41 olan SYSO, uygulama sonrasında 15,30'a yükselmektedir. ÇSYO ise 13,16'dan 14,71'e yükselmektedir

Şekerbank Türk Anonim Şirketi, XXIII. Diğer Hususlara İlişkin Açıklamalar dipnotu TFRS 9 Finansal Araçlar Standardına İlişkin Açıklamalar başlığında, 31.12.2017 tarihli TFRS 9 öncesi finansal tablolar ile 01.01.2018 tarihli TFRS 9 sonrası finansal tablolar arasında bazı mutabakat tablolarına yer vermektedir. Bunlardan finansal varlıklara ilişkin değer düşüş karşılıkları başlıklı bölümde ise toplam değer düşüklüğü karşılıklarında gerçekleşen etki gösterilmektedir. Buna göre; 694.773 TL olan toplam değer düşüklüğü karşılığı, 575.198 TL artarak, 1.269.971 TL'ye yükselmektedir. Bu artış yüzdesel olarak, \%82,79 şeklinde ifade edilebilmektedir. Şekerbank Türk Anonim Şirketi'nin uygulama öncesi 13,11 olan SYSO, uygulama sonrasında 15,40'a yükselmektedir. ÇSYO ise 12,83'ten 12,21'e düşmektedir.

Türkiye İş Bankası Anonim Şirketi, XXIV. Diğer Hususlara İlişkin Açıklamalar dipnotu "TFRS 9-Finansal Araçlar" Standardına İlişkin Açıklamalar başlığında, 31.12.2017 tarihli TFRS 9 öncesi finansal tablolar ile 01.01.2018 tarihli TFRS 9 sonrasi finansal tablolar arasında bazı mutabakat tablolarına yer vermektedir. Değer düşüş karşılıkları başlıklı bölümde ise toplam değer düşüklüğü karşılıklarında gerçekleşen etki gösterilmektedir. Buna göre; 7.735.140 TL olan toplam değer düşüklüğü karşılığı, 80.198 TL artarak, 7.815.338 TL'ye yükselmektedir. $\mathrm{Bu}$ artış yüzdesel olarak, \%1,04 şeklinde ifade edilebilmektedir. Türkiye İş Bankası Anonim Şirketi'nin uygulama öncesi 16,66 olan SYSO, uygulama sonrasında 16,51 'e düşmektedir. ÇSYO ise 14,03 'ten 13,78 'e düşmektedir. 
Yapı ve Kredi Bankası Anonim Şirketi, 1. Sunum esaslarına ilişkin açıklamalar dipnotu "TFRS 9-Finansal Araçlar” Standardına İlişkin Açıklamalar başlığında, 31.12.2017 tarihli TFRS 9 öncesi finansal tablolar ile 01.01.2018 tarihli TFRS 9 sonrası finansal tablolar arasında değer düşüklüğü karşılıklarında gerçekleşen etki gösterilmektedir. Buna göre; 10.418.367 TL olan toplam değer düşüklüğü karşılığ1, 1.046.951 TL artarak, 11.465.318 TL'ye yükselmektedir. Bu artış yüzdesel olarak, \%10,05 şeklinde ifade edilebilmektedir. Yap1 ve Kredi Bankas1 Anonim Şirketi'nin uygulama öncesi 14,49 olan SYSO, uygulama sonrasında 14,02'ye düşmektedir. ÇSYO ise 10,91'den 10,82'ye düşmektedir.

Türkiye Vakıflar Bankası Türk Anonim Ortaklığı, XXVI. Diğer Hususlar dipnotunda 31.12.2017 tarihli TFRS 9 öncesi finansal tablolar ile 01.01.2018 tarihli TFRS 9 sonras1 finansal tablolar arasında bazı mutabakat tablolarına yer vermektedir. Değer düşüş karşılıklarının TFRS 9'a geçişte açılış bakiyelerinin mutabakatı başlıklı bölümde ise toplam değer düşüklüğü karşılıklarında gerçekleşen etki gösterilmektedir. Buna göre; 8.639.366 TL olan toplam değer düşüklüğü karşılığı, 250.367 TL azalarak, 8.388.999 TL'ye düşmektedir. $\mathrm{Bu}$ düşüş yüzdesel olarak, \%2,90 şeklinde ifade edilebilmektedir. Türkiye Vakıflar Bankası Türk Anonim Ortaklığı'nın uygulama öncesi 14,16 olan SYSO, uygulama sonrasında 15,37'ye yükselmektedir. ÇSYO ise 11,47'den 12,22'ye yükselmektedir.

Türkiye Halk Bankası Anonim Şirketi, VI. Finansal Varlıklara İlişkin Açıklamalar dipnotu, Finansal Varlıkların Sinıflandırılması ve Sinıflanan Finansal Varlıkların TFRS 9'a Geçişte Finansal Durum Tablosu Mutabakatı başlığı altında, 31.12.2017 tarihli TFRS 9 öncesi finansal tablolar ile 01.01.2018 tarihli TFRS 9 sonrası finansal tablolar arasında mutabakat tablosuna yer vermektedir. Buna göre; 4.779.272 TL olan toplam değer düşüklüğü karşılığı, 1.831.330 TL artarak, 6.610.602 TL'ye yükselmektedir. Ancak bu düşüşün 2.158.469 TL'si yeniden sınıflandırmaya bağlı artıştan, 327.139 TL'si ise yeniden ölçüme bağlı azalıştan oluşmaktadır. Yeniden ölçüm kaynaklı bu azalış yüzdesel olarak, \%6,85 şeklinde ifade edilebilmektedir. Türkiye Halk Bankası Anonim Şirketi'nin uygulama öncesi 14,18 olan SYSO, uygulama sonrasında 12,01'e düşmektedir. ÇSYO ise 12,56'dan 13,37'ye yükselmektedir.

Türkiye Garanti Bankası Anonim Şirketi, 3.28 Sınıflandırmalar dipnotunda 31.12.2017 tarihli TFRS 9 öncesi finansal tablolar ile 01.01.2018 tarihli TFRS 9 sonras1 finansal tablolar arasında mutabakat tablosuna yer vermektedir. Buna göre; 4.359.237 TL olan toplam değer düşüklüğü karşılığı, 3.355.242 TL artarak, 7.714.479 TL'ye yükselmektedir. Ancak bu yükselişin 3.150.797 TL'si yeniden sınıflandırmaya bağlı artıştan, 204.445 TL'si ise yeniden ölçüme bağlı artıştan oluşmaktadır. Yeniden ölçüm kaynaklı bu artış yüzdesel olarak, \%4,69 şeklinde ifade edilebilmektedir. Türkiye Garanti Bankası Anonim Şirketi'nin uygulama öncesi 18,68 olan SYSO, uygulama sonrasında 18,03'e düşmektedir. ÇSYO ise 16,47 'den 15,82 'ye düşmektedir.

Denizbank Anonim Şirketi, XXIV. TFRS 9 finansal araçlar standardına ilişkin açıklamalar başlıklı dipnotunda, 31.12.2017 tarihli TFRS 9 öncesi finansal tablolar ile 01.01.2018 tarihli TFRS 9 sonrası finansal tablolar arasında bazı mutabakat tablolarına yer vermektedir. Bunlardan değer düşüklüğü karşılıklarının TFRS 9'a geçişte açılış bakiyesinin mutabakatı başlıklı bölümde ise toplam değer düşüklügü karşılıklarında gerçekleşen etki gösterilmektedir. Buna göre; 4.736.714 TL olan toplam değer düşüklüğü karşılığ $1,209.878$ TL artarak, 4.946.592 TL'ye yükselmektedir. Bu yükseliş yüzdesel olarak, \%4,43 şeklinde 
ifade edilebilmektedir. Denizbank Anonim Şirketi'nin uygulama öncesi 19,50 olan SYSO, uygulama sonrasında 19,02'ye düşmektedir. ÇSYO ise 13,67'den 13,35'e düşmektedir.

QNB Finansbank Anonim Şirketi, XXVI. Diğer Hususlara İlişkin Açıklamalar başlıklı dipnotunda, 31.12.2017 tarihli TFRS 9 öncesi finansal tablolar ile 01.01.2018 tarihli TFRS 9 sonrası finansal tablolar arasında bazı mutabakat tablolarına yer vermektedir. Bunlardan TFRS 9 geçiş süreci için değer düşüklüğü karşılıklarının açılış bakiyesi mutabakatı başlıklı bölümde ise toplam değer düşüklüğü karşllıklarında gerçekleşen etki gösterilmektedir. Buna göre; 5.101.253 TL olan toplam değer düşüklüğü karşıllı̆gl, $651.561 \mathrm{TL}$ artarak, 5.752.814 TL'ye yükselmektedir. Bu yükseliş yüzdesel olarak, \%12,77 şeklinde ifade edilebilmektedir. QNB Finansbank Anonim Şirketi'nin uygulama öncesi 14,99 olan SYSO, uygulama sonrasında 14,62'ye düşmektedir. ÇSYO ise 12,32'den 12,09'a düşmektedir.

\section{SONUÇ}

Portföylerinde önemli ölçüde finansal araç bulunduran bankalar üzerindeki olası etkilerini incelemek amacıyla, Avrupa ve Türkiye'nin bankacılık otoriteleri çeşitli çalışmalar yapmıştır. Kamuya açıklanan raporlar karşılaştıııldığında; EBA tarafından yapılan etki analizi ve değerlendirme çalışmalarının BDDK'ya göre daha kapsamlı ve detaylı olduğu, ankette ortaya çıkan beklentiler (ÇSYO, SYSO) ve ayrılan toplam karşılık tutarlarının da birbirinden farklı olduğu gözlenmiştir. Bu paralelde, Aralık 2017 ve Ocak 2018 finansal tablolarına göre ÇSYO'nda artış ve SYSO'da azalış ortaya çıkmış, yeni uygulamaya ilişkin Türkiye'de faaliyette bulunan halka açık bankaların 1 Ocak 2018 tarihli TFRS 9'a geçiş finansal tabloları incelendiğinde ise, EBA'nın öngörüleri ile aynı yönde ve BDDK öngörülerine ters yönde toplam karşılık tutarında artış gözlemlenmiştir. Bunun yanında ertelenmiş vergi varlığı tutarı da artmıştır. $\mathrm{Bu}$ duruma daha önceki mevzuata uygun olarak ayrılan genel ve özel karşılıkların iptal edilerek, birinci ve ikinci aşamadaki krediler için ilk defa ertelenmiş vergi hesaplanması ve bu tutarın açılış finansal durum tablolarına yansıtıllmış olmasının neden olduğu düşünülmektedir. Zira toplam karşllık tutarındaki artış, ilk defa ayrılan ertelenmiş vergi varlığı tutarındaki artışa oranı \%119,98 fazlası olarak gerçekleşmiştir. Bu sebeple, kapsamdaki bankaların toplam özkaynağına olan geçiş etkisi pozitife dönmüştür.

Çalışmanın uygulama kısmında özellikle Türkiye'de faaliyette bulunan halka açık bankaların bağımsız denetim raporlarından yararlanılmış, ancak TFRS 9'a geçiş etkilerinin raporlanması sırasında farklı raporlarda farklı düzey ve detayda bilgilerin raporlandığı görülmüştür. Bu kapsamda, KGK'nın başlatmış olduğu "Elektronik Finansal Raporlama (EFR)" gibi finansal tabloların analizini kolaylaştıran projelerin geliştirilerek geçiş dipnotları ve önemli dipnotlar için de uygulanması gibi düzenleyici kurumlar tarafından özellikle geçiş etkilerinin anlaşılmasını kolaylaştıracak, asgari standartlara ilişkin raporlama biçimleri oluşturulmasının yararlı olabileceği değerlendirilmektedir. 


\section{KAYNAKLAR}

Bankacılık Denetleme ve Düzenleme Kurumu (2017), “Karşılık Yönetmeliği Hakkında Basın Açıklaması”, http://www.bddk.org.tr/ContentBddk/dokuman/duyuru_ 0594_01.pdf (20 Nisan 2019).

Bankacılık Denetleme ve Düzenleme Kurumu (2019), "Türk Bankacılık Sistemi Temel Göstergeleri Aralık 2018”, http:/www.bddk.org.tr/ContentBddk/dokuman/ veri_0014_39.pdf [20 Nisan 2019].

Bottaro, Federica (2017), "The Transition from IAS 39 to IFRS 9: Main Impacts on the Banking Industry (Yayımlanmamış Yüksek Lisans Tezi)", Unıversıta' Degli Studi Di Padova. Padova.

Cohen, Benjamin H. - Edwards Jr, Gerald A. (2017), “The New Era of Expected Credit Loss Provisioning”, BIS Quarterly Review, Mart, 39-56.

Demir, Volkan (2015), TFRS/UFRS Kapsamında Finansal Araçlar, Geliştirilmiş İkinci Basım, Nobel Yayınları, İstanbul.

European Banking Authority (2016), "EBA Report on Results from the EBA Impact Assessment of IFRS 9", https://eba.europa.eu/documents/10180/1360107/EBA+ Report +on+impact+assessment+of+IFRS9 (06 Kasim 2018).

European Banking Authority (2017), "EBA Report on Results from the Second EBA Impact Assessment of IFRS 9", https://eba.europa.eu/documents/10180/ 1720738/EBA+Report+on+results+from+the+2nd+EBA+IFRS9+IA.pdf (06 Kasim 2018).

European Systematic Risk Board (2019), "The cyclical behaviour of the ECL model in IFRS https://www.esrb.europa.eu/pub/pdf/reports/esrb.report190318_reportonthecyclicalbehaviouro ftheECLmodel 2347c3b8da.en.pdf (03 Ağustos 2019)

Kamu Gözetimi, Muhasebe ve Denetim Standartları Kurumu (2019), TFRS 9 Finansal Araçlar'ın Yayımlanmasına İlişkin Kurul Kararı, 15 Ocak 2019 tarihli ve 30656 Sayılı Resmi Gazete. 